UDC 628.349

\title{
Ozonation of woodworking enterprises using a heterogeneous nanocatalyst
}

\author{
Authors: \\ Aliya K. Mazitova, \\ Professor, Head of Applied and Natural Sciences Department, Doctor of Chemistry, Ufa State Petroleum \\ Technological University, Ufa, Bashkortostan Republic, Russia, elenaasf@yandex.ru; \\ Irina A. Sukhareva, \\ Associate Professor, Applied and Natural Sciences Department, PhD in Engineering, Ufa State Petroleum \\ Technological University, Ufa, Republic of Bashkortostan, Russia, e-mail: suxareva-ira@yandex.ru;
}

Alfia F. Aminova,

Postgraduate student, Applied Ecology Department, Ufa State Petroleum Technological University, Ufa, Republic of Bashkortostan, Russia, e-mail: aminovagk@inbox.ru;

Guzel G. Yagafarova,

Professor, Head of Applied Ecology Department, Doctor of Engineering, Ufa State Petroleum Technological University, Ufa, Republic of Bashkortostan, Russia, e-mail: kafedra_ecologia@mail.ru;

Yuliya N. Savicheva,

Associate Professor, Industrial Safety and Labor Protection Department, PhD in Engineering, Ufa State Petroleum Technological University, Ufa, Republic of Bashkortostan, Russia, e-mail: ufa.savjulia@gmail.com

\begin{abstract}
Despite the variety of existing methods of wastewater treatment, this problem can not be considered solved for the woodworking industry. Taking into account that the waste water of plywood-board plants includes phenols, formaldehyde and many other toxic substances, the development of a method for their treatment is an extremely important and actual task. In this regard, we studied the effectiveness of wastewater treatment of the Ufa plywood-board factory (UPBF) by ozonation in the presence of the available and most studied heterogeneous catalysts: $\mathrm{Fe}_{2} \mathrm{O}_{3^{\prime}}$ applied in the form of nanofilms of 0.5-1.0 mm particles $\mathrm{Y}^{-} \mathrm{Al}_{2} \mathrm{O}_{3^{\prime}} \mathrm{Al}_{2} \mathrm{O}_{3^{\prime}}$ applied in the form of nanofilms $2.5-3.0 \mathrm{~mm}$ particles of $\mathrm{TiO}_{2^{\prime}}, \mathrm{MnO}_{2^{\prime}}$ applied in the form of nanofilms $2.5-3.0 \mathrm{~mm}$ particles of TiO ${ }_{2}$. Optimal cleaning conditions were determined by the kinetic curves of phenol decomposition. The results of the conducted experiments on catalytic ozonation of wastewater showed a high purification effect. COD decreased $1.7\left(\mathrm{Al}_{2} \mathrm{O}_{3^{\prime}}, \mathrm{MnO}_{2}\right)$ and 3 times $\left(\mathrm{Fe} \mathrm{O}_{3}\right)$ compared to non-catalyst ozonation. The obtained results allow us to confidently assert that in order to improve the efficiency of treatment of UPBF's wastewater needs ozonation to be carried out in the presence of a heterogeneous nanocatalyst $\mathrm{Fe}_{2} \mathrm{O}_{3^{\prime}}$, which is used in a small amount, so there is no need to purify water from iron (III) ions as in homogeneous catalysis. The concentration of iron ion (III) did not exceed the maximum permissible concentration in drinking water $\left(0.3 \mathrm{mg} / \mathrm{dm}^{3}\right)$. The effect of treatment of COD is up to $96 \%$. The paper presents physical and chemical parameters of the quality of the original wastewater and after ozonation in the presence of the catalyst $\mathrm{Fe}_{2} \mathrm{O}_{3}$. The studied method of purification makes it possible to reduce the content of phenol to the standard quality index $\left(0.01 \mathrm{mg} / \mathrm{dm}^{3}\right)$. Preliminary ozonation of wastewater increases the efficiency of further biological treatment.
\end{abstract}

Keywords: oxidative method, catalytic ozonation, heterogeneous nanocatalyst, sewage disposal of enterprises of wood-based industries.

For citation: Mazitova A.K., Sukhareva I.A., Aminova A.F., Yagafarova G.G., Savicheva Y.N. Ozonation of woodworking enterprises by means of a heterogeneous nanocatalyst. Nanotehnologii v stroitel'stve = Nanotechnologies in Construction. 2019, Vol. 11, no. 4, pp. 394-404. DOI: 10.15828/2075-8545-2019-11-4-394-404.

Machine-readable information on CC-licenses (HTML-code) in metadata of the paper

<a rel="license" href="http://creativecommons.org/licenses/by/4.0/"><img alt="Creative Commons License" style="border-width:0" src="https://i.creativecommons. org/l/by/4.0/88x31.png" / $></ \mathrm{a}><$ br $/><$ span xmlns:dct="http://purl.org/dc/terms/" property="dct:title" $>$ Ozonation of woodworking enterprises by means of a heterogeneous nanocatalyst $</$ span $>$ by $<$ a xmlns:cc="http://creativecommons.org/ns\#" href="Nanotehnologii v stroitel'stve = Nanotechnologies in Construction. 2019, Vol. 11, no. 4, pp. 394-404. DOI: 10.15828/2075-8545-2019-11-4-394-404" property="cc:attributionName" rel="cc:attributionURL" $>$ Mazitova A.K., Sukhareva I.A., Aminova A.F., Yagafarova G.G., Savicheva Y.N.</a > is licensed under a <a rel="license" href="http://creativecommons.org/licenses/by/4.0/" $>$ Creative Commons Attribution 4.0 International License $</ a>.<$ br / $>$ Based on a work at $<$ a xmlns:dct="http://purl.org/dc/terms/" href="http://nanobuild.ru/en_EN/nanobuild-4-2019/" rel="dct:source" $>$ http://nanobuild.ru/en_EN/nanobuild-4-2019/</a $>$.<br $/>$ Permissions beyond the scope of this license may be available at $<$ a xmlns:cc="http://creativecommons.org/ns\#" href="suxareva-ira@yandex.ru" rel="cc:morePermissions" $>$ suxareva-ira@yandex.ru</a $>$. 


\title{
Озонирование сточных вод предприятий деревообрабатывающей промышленности с применением гетерогенного нанокатализатора
}

\author{
Авторы: \\ Мазитова Алия Карамовна, \\ профессор, ФГБОУ ВО «Уфимский государственный нефтяной технический университет», Россия, \\ Республика Башкортостан, г. Уфа, e-mail: elenaasf@yandex.ru;

\section{Сухарева Ирина Александровна,} \\ доцент кафедры, ФГБОУ ВО «Уфимский государственный нефтяной технический университет», Россия, \\ Республика Башкортостан, г. Уфа, e-mail: suxareva-ira@yandex.ru;
}

\section{Аминова Альфия Фатыховна,}

аспирант кафедры, ФГБОУ ВО «Уфимский государственный нефтяной технический университет», Россия, Республика Башкортостан, г. Уфа, e-mail: aminovagk@inbox.ru;

\section{Ягафарова Гузель Габдулловна,}

зав. кафедрой, ФГБОУ ВО «Уфимский государственный нефтяной технический университет», Россия,

Республика Башкортостан, г. Уфа, e-mail: kafedra_ecologia@mail.ru;

\section{Савичева Юлия Николаевна,}

доцент кафедры , ФГБОУ ВО «Уфимский государственный нефтяной технический университет», Россия, Республика Башкортостан, г. Уфа, e-mail: ufa.savjulia@gmail.com

Резюме: Несмотря на многообразие существующих способов очистки сточных вод эту проблему нельзя считать решенной для предприятий деревообрабатывающей промышленности. Учитывая, что в состав сточных вод фанерно-плитных комбинатов входят фенолы, формальдегид и многие другие токсичные вещества, разработка способа их очистки является крайне важной и актуальной задачей. В связи с этим нами проведено исследование эффективности очистки сточных вод уфимского фанерно-плитного комбината (УФПК) озонированием в присутствии доступных и наиболее изученных гетерогенных катализаторов: $\mathrm{Fe}_{2} \mathrm{O}_{3^{\prime}}$ нанесенного в виде наноплёнки на 0,5-1,0 мм частицы ү-Al2O3; Al2O3, нанесенного в виде наноплёнки на 2,5-3,0 мм частицы $\mathrm{TiO}_{2}, \mathrm{MnO}_{2}$, нанесенного в виде наноплёнки на 2,5-3,0 мм частицы ТіО, Оптимальные условия очистки определяли по кинетическим кривым разложения фенола. Результаты проведённых экспериментов по каталитическому озонированию сточных вод показали высокий эффект очистки. ХПК снизилось в 1,7 ( $\left.\mathrm{Al}_{2} \mathrm{O}_{3^{\prime}} \mathrm{MnO}_{2}\right)$ и в 3 раза $\left(\mathrm{Fe}_{2} \mathrm{O}_{3}\right)$ по сравнению с озонированием без катализатора. Полученные результаты позволяют уверенно утверждать, что для повышения эффективности очистки сточных вод УФПК необходимо озонирование проводить в присутствии гетерогенного нанокатализатора $\mathrm{Fe}_{2} \mathrm{O}_{3}$, который используется в небольшом количестве, поэтому отсутствует необходимость очищения воды от ионов железа (III) в гомогенном катализе. Концентрация иона железа (III) не превышала предельно-допустимую концентрацию в питьевой воде (0,3 мг/дм³). Эффект очистки по ХПК достигает 96\%. В работе приведены физико-химические показатели качества исходной сточной воды и после озонирования в присутствии катализатора $\mathrm{Fe}^{2} \mathrm{O}^{3}$. Исследованный способ очистки позволяет снизить содержание фенола до нормативного показателя качества (0,01 мг/дм³). Предварительное озонирование сточных вод повышает эффективность дальнейшей биологической очистки.

Ключевые слова: окислительный метод, каталитическое озонирование, гетерогенный нанокатализатор, сточные воды деревообрабатывающей промышленности.

Для цитирования: Мазитова А.К., Сухарева И.А., Аминова А.Ф., Ягафарова Г.Г., Савичева Ю.Н. Озонирование сточных вод предприятий деревообрабатывающей промышленности с применением гетерогенного нанокатализатора // Нанотехнологии в строительстве. - 2019. - Том 11, № 4. - С. 394-404. - DOI: 10.15828/2075-8545-2019-11-4-394-404. 
Машиночитаемая информация о CС-лицензиях (HTML-код) в метаданных статьи

$<$ a rel="license" href="http://creativecommons.org/licenses/by/4.0/"><img alt="Creative Commons License" style="border-width:0" src="https://i.creativecommons. org/l/by/4.0/88x31.png" / $></$ a $><$ br $/><$ span xmlns:dct="http://purl.org/dc/terms/" property="dct:title" $>$ Ozonation of woodworking enterprises by means of a heterogeneous nanocatalyst $</$ span $>$ by $<$ a xmlns:cc="http://creativecommons.org/ns\#" href="Nanotehnologii v stroitel'stve = Nanotechnologies in Construction 2019, Vol. 11, no. 4, pp. 394-404. DOI: 10.15828/2075-8545-2019-11-4-394-404" property="cc:attributionName" rel="cc:attributionURL" $>$ Mazitova A.K., Sukhareva I.A., Aminova A.F., Yagafarova G.G., Savicheva Y.N. $</$ a $>$ is licensed under a $<$ a rel="license" href="http://creativecommons.org/licenses/by/4.0/" $>$ Creative Commons Attribution 4.0 International License</a $>$. <br/>Based on a work at $<$ a xmlns:dct="http://purl.org/dc/terms/" href="http://nanobuild.ru/en_EN/nanobuild-4-2019/" rel="dct:source" $>$ http://nanobuild.ru/en_EN/nanobuild-4-2019/</a $>$. $<\mathrm{br} />$ Permissions beyond the scope of this license may be available at $<$ a xmlns:cc="http://creativecommons.org/ns\#" href="suxareva-ira@yandex.ru" rel="cc:morePermissions" $>$ suxareva-ira@yandex.ru</a $>$.

Статья поступила в редакцию: 28.06.2019.

Статья поступила в редакцию после рецензирования: 19.07.2019.

Статья принята к публикации: 29.07.2019.

\section{INTRODUCTION}

$\mathrm{T}$ he complex physical and chemical composition of wastewater pollution in the production of fibreboard causes significant costs for the operation of treatment facilities that use almost all treatment methods. Despite the variety of existing methods of wastewater treatment, this problem can not be considered solved for plywood-plate plants. One should note that the wastewater of the Ufa plywood-board plant (UPBF) includes phenols, formaldehyde and many other toxic substances, therefore the development of a method for their treatment is an extremely important and urgent task. It is known that the oxidative method of ozone purification is effective for the destruction of such substances [1-8]. Ozone has a high standard redox potential $(2.07 \mathrm{~V})$ and therefore practically decomposes many organic compounds. During the chemical transformation of ozone under the action of hydrogen peroxide, catalysts, activated carbon, ultrasound, hydroxyl radicals with stronger oxidizing properties $(2,70 \mathrm{~V})$ are formed in the solution [9]. It is known from the literature that the use of catalysts in the ozonation process can improve the efficiency of wastewater treatment [10-22]. In this regard, we conducted a study of the effectiveness of the mentioned above wastewater treatment by ozonation in the presence of available and most studied heterogeneous nanocatalysts $\left(\mathrm{Fe}_{2} \mathrm{O}_{3}, \mathrm{Al}_{2} \mathrm{O}_{3}, \mathrm{MnO}_{2}\right)$.

\section{MAIN PART}

The procedure of the experiments on ozonation of wastewater in the presence of heterogeneous nanocatalyst

The composition of the initial investigated water is given in table.

For the production of ozone the generator OGVK-02K was used, to provide input of ozone-oxygen mixture in water and contact with impurities used - a reactor with volume $1 \mathrm{dm}^{3}$; the control device of ozone concentration in the water - photometer «Expert-003». The catalyst with weight $1 \mathrm{~g}$ was loaded into the ozonator tank in the form of spherical particles. As the catalyst $\mathrm{Fe}_{2} \mathrm{O}_{3}$ applied in the form of nanofilms on $0.5-1.0 \mathrm{~mm}$ particles $\gamma-\mathrm{Al}_{2} \mathrm{O}_{3}$; $\mathrm{Al}_{2} \mathrm{O}_{3}$, applied in the form of nanofilms on $2.5-3.0 \mathrm{~mm}$ particles of $\mathrm{TiO}_{2} ; \mathrm{MnO}_{2}$, applied in the form of nanofilms on 2.5-3.0 mm particles of $\mathrm{TiO}_{2}$ were used. Ozone was fed into the treated water with the use of a porous ceramic disperser. Oxidation was carried out in a non-flowing mode with intensive mixing of the catalyst on a magnetic stirrer in the draught cupboard. Ozone concentration in the air of the working area was controlled by indicator tubes TI[O3-0.003], it should not exceed $0.0001 \mathrm{mg} / \mathrm{dm}^{3}$. After 5-40 minutes of mixing in the presence of ozone, wastewater was separated from the catalyst and the COD index was determined by titrimetric method (ERD F 14.1:2:3. 100-97). pH was measured at the pH-meter ANION 4100. The concentration of iron (III) ions in wastewater was controlled by the spectrophotometer RV2201.

Results of experiments on the study of wastewater ozonation in the presence of heterogeneous nanocatalyst

Tentatively we have chosen the optimum $\mathrm{pH}$ of the wastewater for carrying out catalytic ozonation. The best results were obtained at $\mathrm{pH}=9.9-10.4$ (Fig. 1). Therefore, before oxidation, wastewater was mechanically purified and alkalized to $\mathrm{pH}=9.9-10.4$. The influence of wastewater temperature (Fig. 2) and ozone doses (Fig. 3) on the residual concentration of phenol has also been investigated. The lowest residual phenol concentration was achieved at $22-24^{\circ} \mathrm{C}$ and the optimal ozone dose was $5 \mathrm{~g} / \mathrm{dm}^{3}$.

The results of the experiments on catalytic ozonation of wastewater showed high efficiency of this method, 
Table

Wastewater description

\begin{tabular}{|c|c|c|c|c|}
\hline \multirow[b]{2}{*}{ № } & \multirow[b]{2}{*}{ Water quality indicators } & \multicolumn{2}{|c|}{ Analysis result } & \multirow{2}{*}{$\begin{array}{l}\text { Regulatory document on } \\
\text { the procedure (method) of } \\
\text { measurements }\end{array}$} \\
\hline & & $\begin{array}{l}\text { Initial } \\
\text { wastewater }\end{array}$ & $\begin{array}{c}\text { Wastewater after } \\
\text { treatment } \mathrm{O}_{3} \\
\text { and } \mathrm{Fe}_{2} \mathrm{O}_{3}\end{array}$ & \\
\hline 1 & Hydrogen index (units $\mathrm{pH}$ ) & $4,4 \pm 0,2$ & $10,0 \pm 0,2$ & ERD F 14.1:2:3:4. 121-97 \\
\hline 2 & $\mathrm{COD}, \mathrm{mgO}_{2} / \mathrm{dm}^{3}$ & $7600 \pm 1140$ & $304 \pm 46$ & ERD F 14.1:2:3. 100-97 \\
\hline 3 & BOD5, $\mathrm{mgO}_{2} / \mathrm{dm}^{3}$ & $3297 \pm 396$ & $560 \pm 67$ & ERD F 14.1:2:3:4. 123-97 \\
\hline 4 & Suspended solids, $\mathrm{mg} / \mathrm{dm}^{3}$ & $3127 \pm 165$ & $45 \pm 3$ & ERD F 14.1:2:4. 254-09 \\
\hline 5 & $\begin{array}{l}\text { Phenols (volatile with } \\
\text { steam), } \mathrm{mg} / \mathrm{dm}^{3}\end{array}$ & $0,263 \pm 0,042$ & $0,008 \pm 0,002$ & ERD F 14.1:2. 105-97 \\
\hline 6 & Oil products, $\mathrm{mg} / \mathrm{dm}^{3}$ & $26 \pm 2$ & $0,07 \pm 0,01$ & ERD F 14.1:2:4. 5-95 \\
\hline 7 & $\mathrm{Cl}^{-}, \mathrm{mg} / \mathrm{dm}^{3}$ & $30 \pm 2$ & $25 \pm 2$ & ERD F 14.1:2:4. 111-97 \\
\hline 8 & $\mathrm{SO}_{4}^{3-}, \mathrm{mg} / \mathrm{dm}^{3}$ & $136 \pm 16$ & $111 \pm 12$ & ERD F 14.1:2:3:4.240-2007 \\
\hline 9 & $\mathrm{NH}_{4}^{+}, \mathrm{mg} / \mathrm{dm}^{3}$ & $31 \pm 7$ & $48 \pm 12$ & ERD F 14.1:2. 1-95 \\
\hline 10 & $\mathrm{NO}_{2}^{-}, \mathrm{mg} / \mathrm{dm}^{3}$ & $<0,02$ & $<0,04$ & ERD F 14.1:2:4.3-95 \\
\hline 11 & $\mathrm{PO}_{4}^{3-}(\mathrm{P}), \mathrm{mg} / \mathrm{dm}^{3}$ & $2,5 \pm 0,2$ & $0,30 \pm 0,02$ & ERD F 14.1:2:4. 112-97 \\
\hline 12 & ASSAS* $\mathrm{mg} / \mathrm{dm}^{3}$ & $1,10 \pm 0,09$ & $0,24 \pm 0,03$ & ERD F 14.1:2:4. 15-95 \\
\hline
\end{tabular}

Note: ASSAS* - anionic synthetic surface-active substances

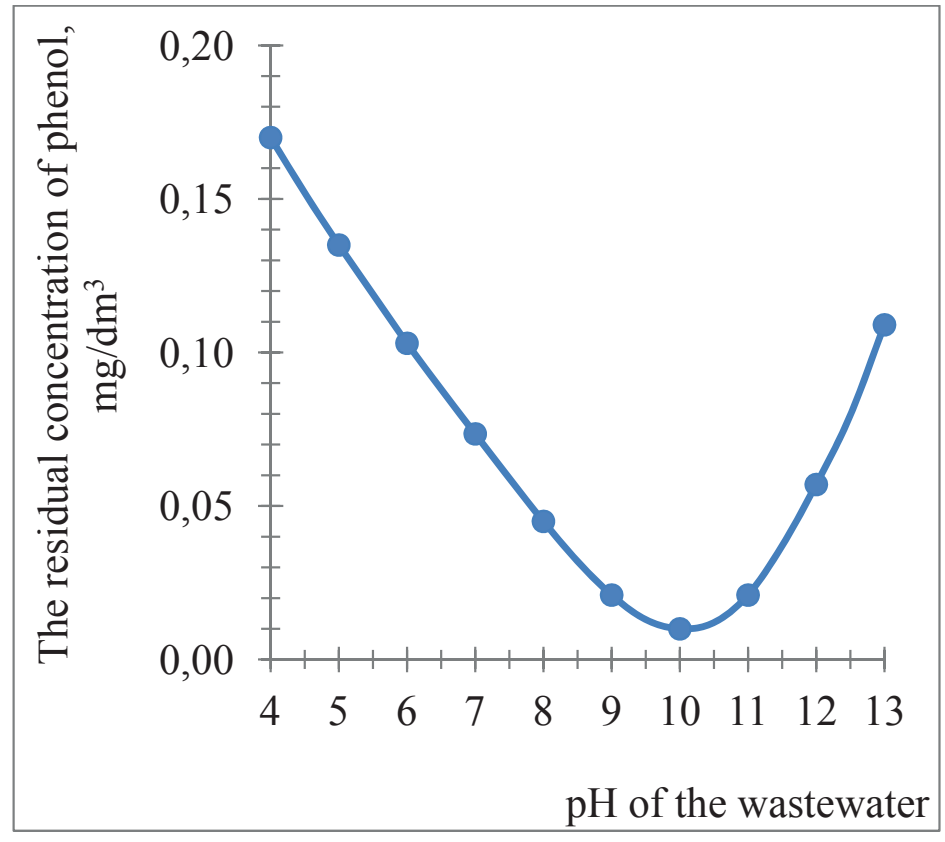

Fig. 1. Effect of $\mathrm{pH}$ on the residual concentration of phenol in wastewater during catalytic $\left(\mathrm{Fe}_{2} \mathrm{O}_{3}\right)$ ozonation (duration $35 \mathrm{~min}$, temperature $22-24^{\circ} \mathrm{C}$, ozone dose $\left.-5 \mathrm{~g} / \mathrm{dm}^{3}\right)$ 


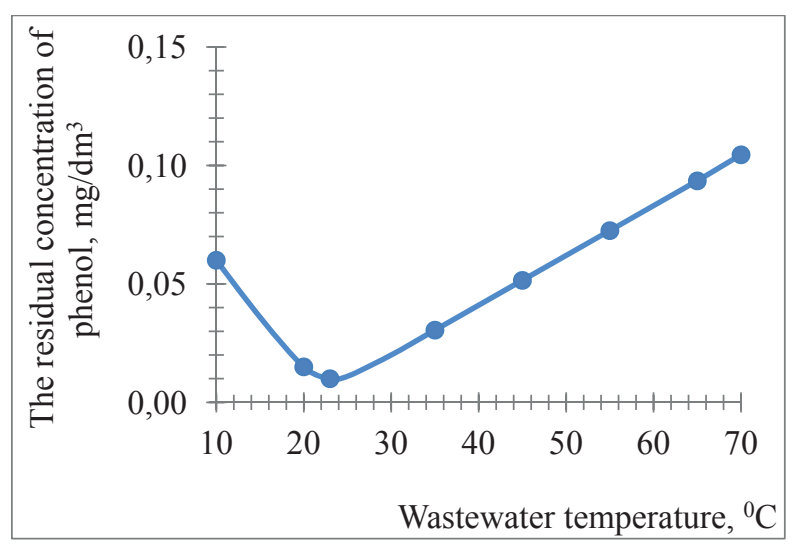

Fig. 2. Effect of wastewater temperature on the residual concentration of phenol in catalytic $\left(\mathrm{Fe}_{2} \mathrm{O}_{3}\right)$ ozonation (duration $-35 \mathrm{~min}, \mathrm{pH}=9.9-10.4$, ozone dose $\left.5 \mathrm{~g} / \mathrm{dm}^{3}\right)$

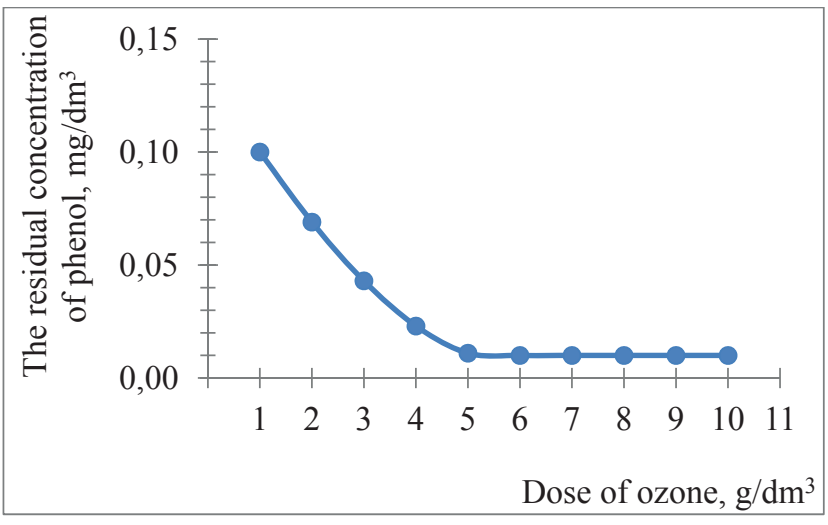

Fig. 3. Effect of ozone dose on the residual concentration of phenol in catalytic $\left(\mathrm{Fe}_{2} \mathrm{O}_{3}\right)$ ozonation (duration $35 \mathrm{~min}, \mathrm{pH}=9.9-10.4$, temperature $\left.-22-24^{\circ} \mathrm{C}\right)$

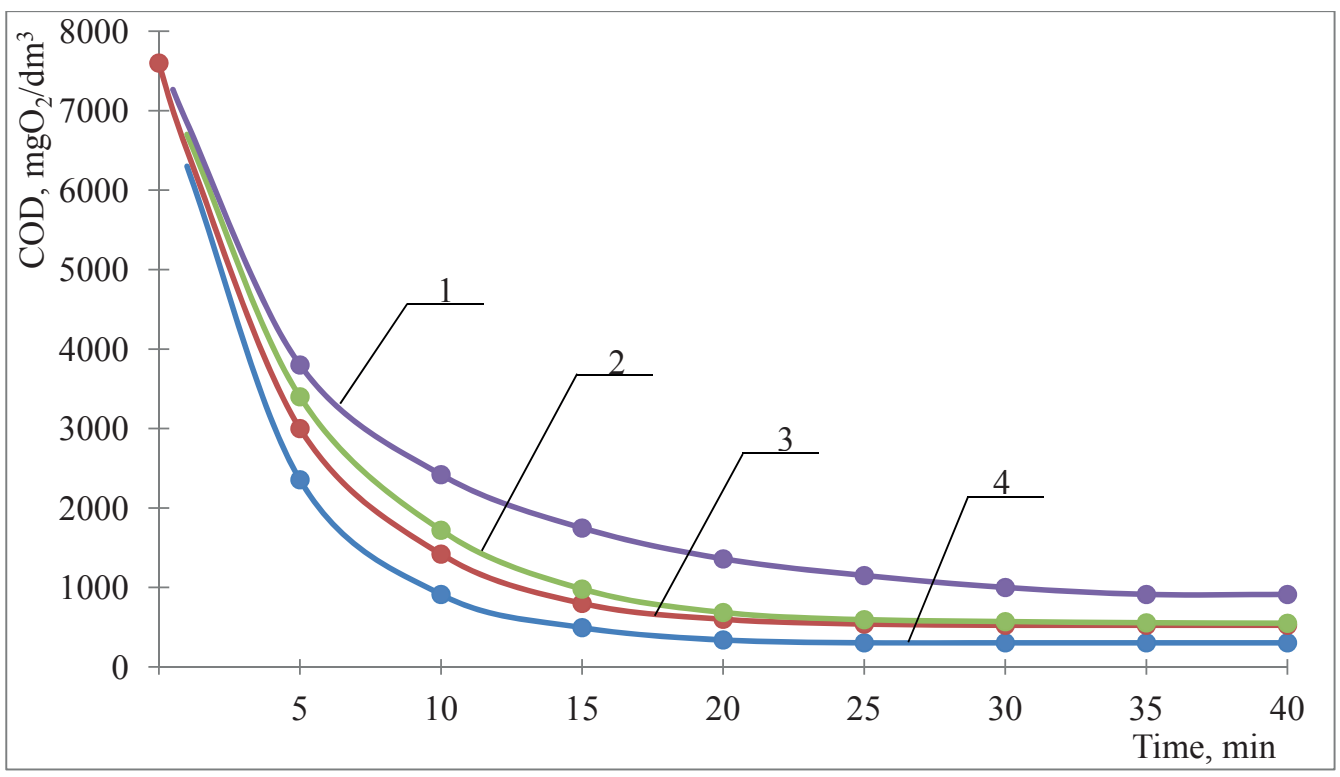

Fig. 4. Curves of COD change in wastewater during ozonation: without catalyst (curve 1), in the presence of $\mathrm{Al}_{2} \mathrm{O}_{3}$ catalyst (curve 2), in the presence of $\mathrm{MnO}_{2}$ catalyst (curve 3), in the presence of $\mathrm{Fe}_{2} \mathrm{O}_{3}$ catalyst (curve 4)

which makes it possible to reduce COD in $1,7\left(\mathrm{Al}_{2} \mathrm{O}_{3}\right.$, $\left.\mathrm{MnO}_{2}\right)$ and 3 times $\left(\mathrm{Fe}_{2} \mathrm{O}_{3}\right)$ compared with conventional ozonation (Fig. 4).

After ozonation in the presence of the $\mathrm{Fe}_{2} \mathrm{O}_{3}$ catalyst, the concentration of iron (III) ions in wastewater was controlled by spectrophotometric method (ERD F 14.1:2:4.50-96). Concentration of ion did not exceed MPC in drinking water $\left(0.3 \mathrm{mg} / \mathrm{dm}^{3}\right)$. The physico-chemical characteristics of the treated wastewater are given in table 1 .

\section{SUMMARY}

The results obtained allow us to confidently assert that to improve the efficiency of wastewater treatment of UPBF it is necessary to carry out ozonation in the presence of heterogeneous nanocatalyst $\mathrm{Fe}_{2} \mathrm{O}_{3}$, which is used in small quantities. The studied method of purification makes it possible to reduce the content of phenol to the standard quality index. The effect of treatment of COD is up to $96 \%$. 


\section{ВВЕДЕНИЕ}

$\mathrm{C}$ ложный физико-химический состав загрязнений сточных вод производства древесноволокнистых плит требует значительных затрат на эксплуатацию очистных сооружений с использованием практически всех методов очистки. Несмотря на многообразие существующих способов очистки сточных вод эту проблему нельзя считать решенной для фанерно-плитных комбинатов. Учитывая, что в состав сточных вод уфимского фанерно-плитного комбината (УФПК) входят фенолы, формальдегид и многие другие токсичные вещества, разработка способа их очистки является крайне важной и актуальной задачей. Известно, что для деструкции таких веществ эффективен окислительный метод очистки с помощью озона [1-8]. Озон обладает высоким стандартным окислительно-восстановительным потенциалом (2,07 в), поэтому практически разлагает многие органические соединения. При химической трансформации озона под действием пероксида водорода, катализаторов, активированного угля, ультразвука в растворе образуются гидроксильные радикалы с более сильными окислительными свойствами (2,70 в) [9]. Из литературных данных известно, что использование катализаторов в процессе озонирования позволяет повысить эффективность очистки сточных вод [10-22]. В связи с этим нами проведено исследование эффективности очистки вышеуказанных сточных вод озонированием в присутствии доступных и наиболее изученных гетерогенных нанокатализаторов $\left(\mathrm{Fe}_{2} \mathrm{O}_{3}, \mathrm{Al}_{2} \mathrm{O}_{3}, \mathrm{MnO}_{2}\right)$.

\section{ОСНОВНАЯ ЧАСТЬ}

Методика проведения экспериментов по озонированию сточных вод в присутствии гетерогенного нанокатализатора

Состав исходной исследуемой воды приведен в табл.

Для производства озона использовали озоногенератор ОГВК-02К, для обеспечения ввода озонокислородной смеси в воду и контакта с примесями - реактор объемом 1 дм³; прибор контроля концентрации озона в воде - фотометр «Эксперт-003». Катализатор массой 1 г загружали в озонаторную емкость в виде сферических частиц. В качестве катализатора использовали $\mathrm{Fe}_{2} \mathrm{O}_{3}$, нанесенный в виде нанопленки на $0,5-1,0$ мм частицы $\gamma-\mathrm{Al}_{2} \mathrm{O}_{3} ; \mathrm{Al}_{2} \mathrm{O}_{3}$,

\section{Таблииа}

Характеристика сточных вод

\begin{tabular}{|c|c|c|c|c|}
\hline \multirow[b]{2}{*}{$\begin{array}{l}\text { № } \\
\text { П/ா/I }\end{array}$} & \multirow[b]{2}{*}{$\begin{array}{c}\text { Показатели } \\
\text { качества воды }\end{array}$} & \multicolumn{2}{|c|}{ Результат анализа } & \multirow[b]{2}{*}{$\begin{array}{c}\text { Нормативный документ } \\
\text { на методику (метода) } \\
\text { измерений }\end{array}$} \\
\hline & & $\begin{array}{c}\text { Исходная } \\
\text { сточная вода }\end{array}$ & $\begin{array}{c}\text { Сточная вода } \\
\text { после обработки } \\
\mathrm{O}_{3} \text { и } \mathrm{Fe}_{2} \mathrm{O}_{3} \\
\end{array}$ & \\
\hline 1 & Водородный показатель (ед.рН) & $4,4 \pm 0,2$ & $10,0 \pm 0,2$ & ПНД Ф 14.1:2:3:4. 121-97 \\
\hline 2 & $\mathrm{XПК,} \mathrm{мгО} 2 /$ дм $^{3}$ & $7600 \pm 1140$ & $304 \pm 46$ & ПНД Ф 14.1:2:3. 100-97 \\
\hline 3 & БПК $5, \mathrm{мгO}_{2} / д \mathrm{M}_{3}$ & $3297 \pm 396$ & $560 \pm 67$ & ПНД Ф 14.1:2:3:4. 123-97 \\
\hline 4 & Взвешенные вещества, мг/дм³ & $3127 \pm 165$ & $45 \pm 3$ & ПНД Ф 14.1:2:4. 254-09 \\
\hline 5 & Фенолы (летучие с паром), мг/дм³ & $0,263 \pm 0,042$ & $0,008 \pm 0,002$ & ПНД Ф 14.1:2. 105-97 \\
\hline 6 & Нефтепродукты, мг/дм ${ }^{3}$ & $26 \pm 2$ & $0,07 \pm 0,01$ & ПНД Ф 14.1:2:4. 5-95 \\
\hline 7 & $\mathrm{Cl}^{-}, \mathrm{мг} / д \mathrm{M}^{3}$ & $30 \pm 2$ & $25 \pm 2$ & ПНД Ф 14.1:2:4. 111-97 \\
\hline 8 & $\mathrm{SO}_{4}^{3-}$, мг/дм ${ }^{3}$ & $136 \pm 16$ & $111 \pm 12$ & ПНД Ф 14.1:2:3:4.240-2007 \\
\hline 9 & $\mathrm{NH}_{4}^{+}$, мг $/ д \mathrm{M}^{3}$ & $31 \pm 7$ & $48 \pm 12$ & ПНД Ф 14.1:2. 1-95 \\
\hline 10 & $\mathrm{NO}_{2}^{-}$, мг/дм ${ }^{3}$ & $<0,02$ & $<0,04$ & ПНД Ф 14.1:2:4.3-95 \\
\hline 11 & $\mathrm{PO}_{4}^{3-}(\mathrm{P})$, мг $/$ Дм ${ }^{3}$ & $2,5 \pm 0,2$ & $0,30 \pm 0,02$ & ПНД Ф 14.1:2:4. 112-97 \\
\hline 12 & АСПАВ*, мг/дм ${ }^{3}$ & $1,10 \pm 0,09$ & $0,24 \pm 0,03$ & ПНД Ф 14.1:2:4. 15-95 \\
\hline
\end{tabular}

Примечание: АСПАВ* - анионные синтетические поверхностно-активные вещества. 
нанесенный в виде нанопленки на 2,5-3,0 мм частицы $\mathrm{TiO}_{2}, \mathrm{MnO}_{2}$, нанесенный в виде нанопленки на 2,5-3,0 мм частицы $\mathrm{TiO}_{2}$. В обрабатываемую воду озон подавали с помощью пористого керамического диспергатора. Окисление проводили в непроточном режиме при интенсивном перемешивании катализатора на магнитной мешалке в вытяжном шкафу. Концентрацию озона в воздухе рабочей зоны контролировали с помощью индикаторных трубок ТИ-[О3-0,003], она не должна превышать 0,0001 мг/дм ${ }^{3}$. После 5-40 минут перемешивания в присутствии озона сточную воду отделяли от ка- тализатора и определяли показатель ХПК титриметрическим методом (ПНД Ф 14.1:2:3. 100-97). РН измеряли на рН-метре АНИОН 4100 . Концентрацию ионов железа (III) в сточной воде контролировали на спектрофотометре РВ2201.

Результаты экспериментов по исследованию озонирования сточных вод в присутствии гетерогенного нанокатализатора

Предварительно нами подобрано оптимальное значение $\mathrm{pH}$ сточной воды для проведения каталити-

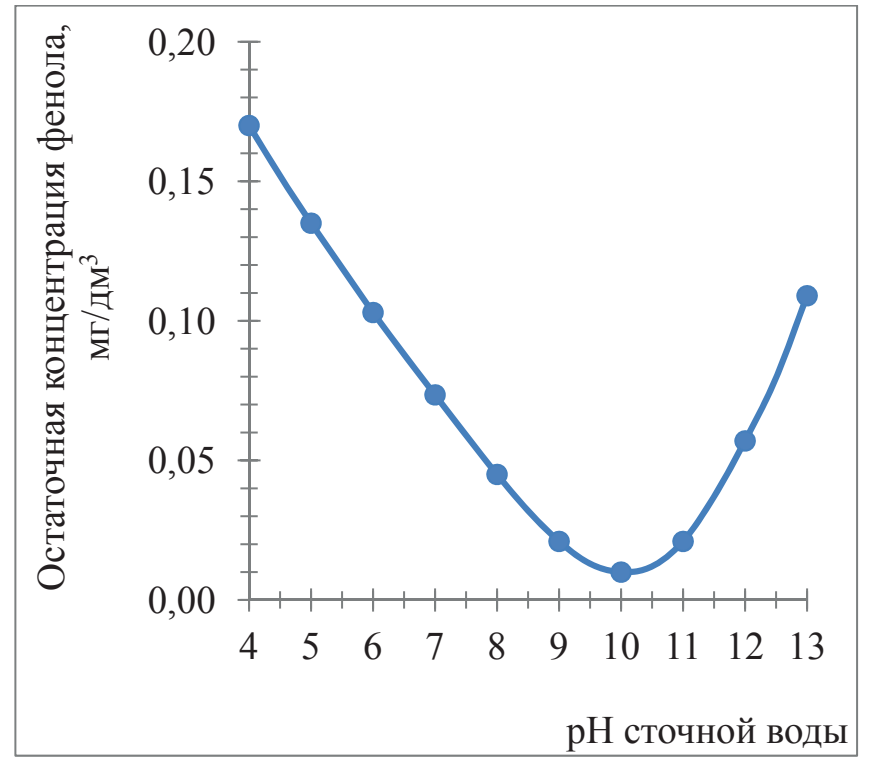

Рис. 1. Влияние рН на остаточную концентрацию фенола в сточной воде при каталитическом $\left(\mathrm{Fe}_{2} \mathrm{O}_{3}\right)$ озонировании (продолжительность - 35 мин, температура $22-24^{\circ} \mathrm{C}$, доза озона -5 г/дм ${ }^{3}$ )

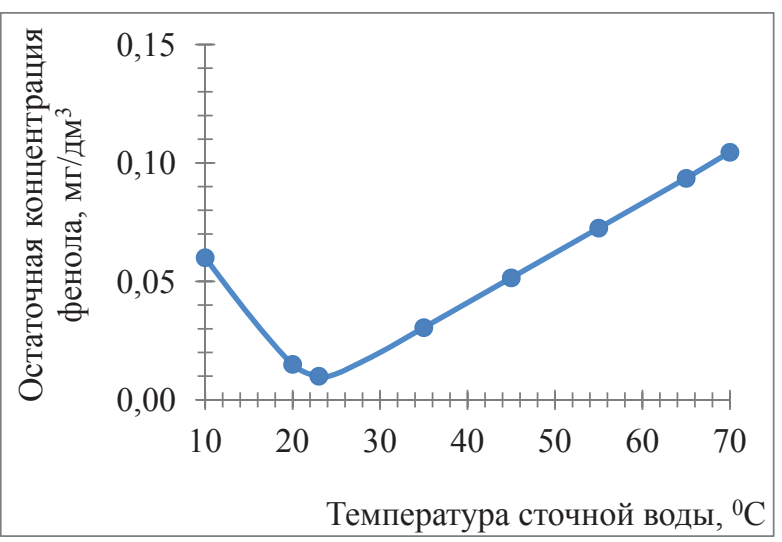

Рис. 2. Влияние температуры сточной воды на остаточную концентрацию фенола при каталитическом $\left(\mathrm{Fe}_{2} \mathrm{O}_{3}\right)$ озонировании (продолжительность - 35 мин, pH = 9,9-10,4, доза озона -5 г/дм³)

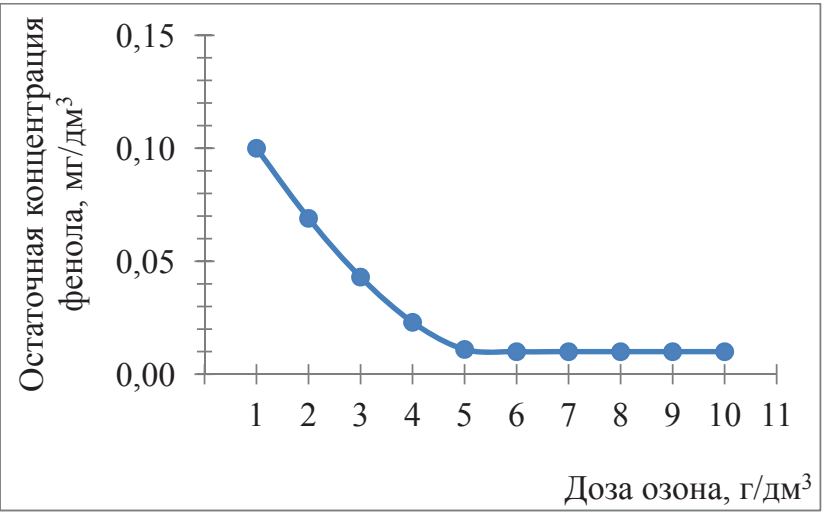

Рис. 3. Влияние дозы озона на остаточную концентрацию фенола при каталитическом $\left(\mathrm{Fe}_{2} \mathrm{O}_{3}\right)$ озонировании (продолжительность - 35 мин, $\mathrm{pH}=9,9-10,4$, температура $-22-24^{\circ} \mathrm{C}$ ) 


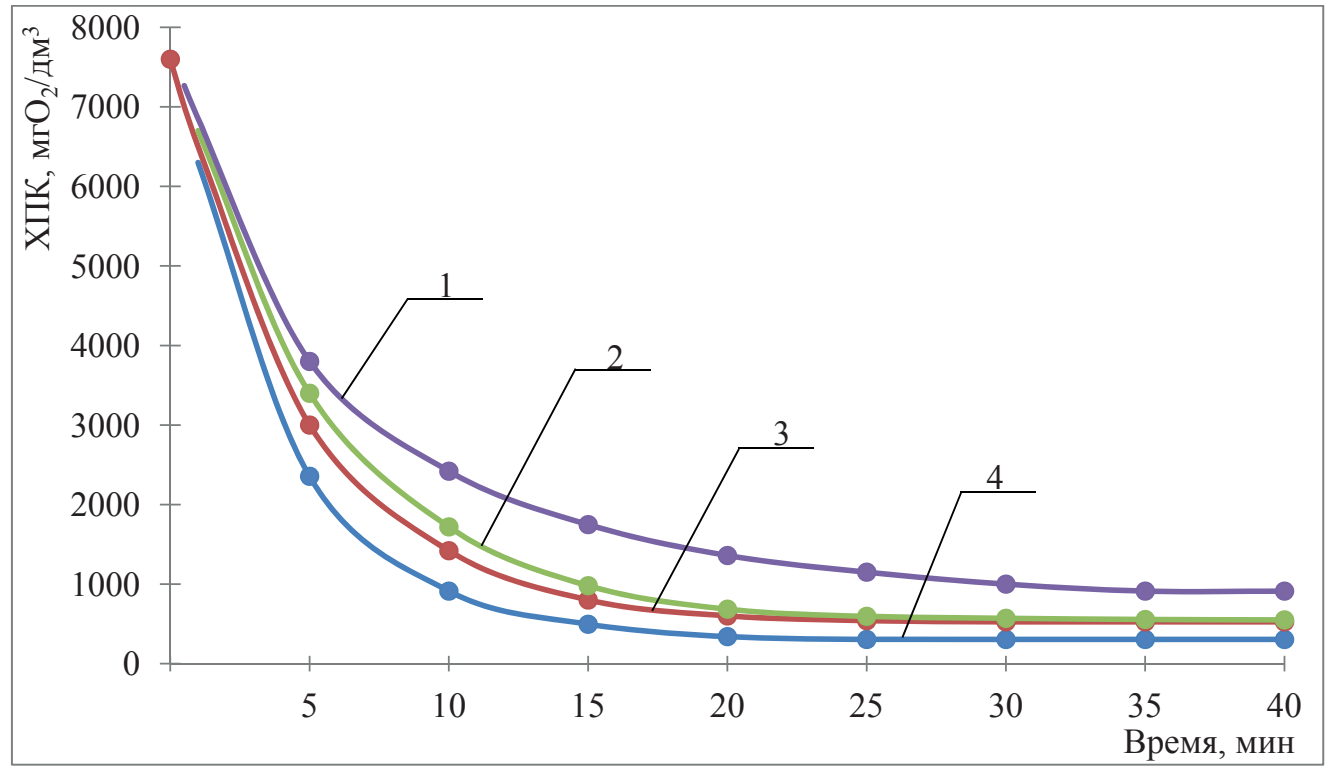

Рис. 4. Кривые изменения показателя ХПК в сточной воде при озонировании: без катализатора (кривая 1), в присутствии катализатора $\mathrm{Al}_{2} \mathrm{O}_{3}$ (кривая 2), в присутствии катализатора $\mathrm{MnO}_{2}$ (кривая 3), в присутствии катализатора $\mathrm{Fe}_{2} \mathrm{O}_{3}$ (кривая 4).

ческого озонирования. Лучшие результаты получены при $\mathrm{pH}=9,9-10,4$ (рис. 1). Поэтому перед окислением сточную воду подвергали механической очистке и подщелачивали до $\mathrm{pH}=9,9-10,4$. Также исследовано влияние температуры сточной воды (рис. 2) и дозы озона (рис. 3) на остаточную концентрацию фенола. Самая низкая остаточная концентрация фенола была достигнута при $22-24^{\circ} \mathrm{C}$, а оптимальная доза озона составила 5 г/дм³.

Результаты проведенных экспериментов по каталитическому озонированию сточных вод показали высокую эффективность данного метода, позволяющего снизить ХПК в $1,7\left(\mathrm{Al}_{2} \mathrm{O}_{3}, \mathrm{MnO}_{2}\right)$ и в 3 раза $\left(\mathrm{Fe}_{2} \mathrm{O}_{3}\right)$ по сравнению с обычным озонированием (рис. 4).

После озонирования в присутствии катализатоpa $\mathrm{Fe}_{2} \mathrm{O}_{3}$ контролировали концентрацию ионов же- леза (III) в сточной воде спектрофотометрическим методом (ПНД Ф 14.1:2:4.50-96). Концентрация иона не превышала ПДК в питьевой воде $(0,3$ мг/дм $)$. Физико-химические характеристики очищенной сточной воды приведены в табл.

\section{ВЫВОДЫ}

Полученные результаты позволяют уверенно утверждать, что для повышения эффективности очистки сточных вод УФПК необходимо озонирование проводить в присутствии гетерогенного нанокатализатора $\mathrm{Fe}_{2} \mathrm{O}_{3}$, который используется в небольшом количестве. Исследованный способ очистки позволяет снизить содержание фенола до нормативного показателя качества. Эффект очистки по ХПК достигает $96 \%$. 


\section{REFERENCES}

1. Pisarenko A.N., Stanford B.D., Yan D., Gerrity D., Snyder S.A. Effects of ozone and ozone/peroxide on trace organic contaminants and NDMA in drinking water and water reuse applications. Water Research. 2012. V. 46. P. 316-326. doi: 10.1016/j. watres.2011.10.021.

2. Uschenko V.P., Popov Yu.V., Voronovich N.V., Uzakov E.Yu., Pavlova S.V. Ozonirovanie kak sposob ochistki stochnyh vod ot aromaticheskih soedinenij [Ozonization as a method of purification of sewage from aromatic compounds]. IZVESTIYa VolgGTU. 2008. Vol. 5. No. 1 (39). P. 79-81 (in Russian).

3. Katsoyiannis I.A., Canonisa S., von Gunten U. Efficiency and energy requirements for the transformation of organic micropollutants by ozone, $\mathrm{O}_{3} / \mathrm{H}_{2} \mathrm{O}_{2}$ and UV/ $\mathrm{H}_{2} \mathrm{O}_{2}$. Water Research. 2011. V. 45. P. 3811-3822. DOI: 10.1016/j.watres.2011.04.038.

4. Draginsky V.L., Alekseeva V.A., Usoltsev V.A. Povyshenie jeffektivnosti ochistki vody s ispol'zovaniem tehnologii ozonirovanija i sorbcii na aktivnyh ugljah [Increasing of the efficiency of water treatment using the technology of ozonization and sorption on active coals]. Vodosnabzheniye i sanitarnaya tekhnika [Water Supply and Sanitary Technique]. 1995. Issue 5. P. 8-10 (in Russian).

5. Selyukov A.V., Bursova S.N., Trinko A.I. Primenenie jekologicheski chistyh okislitelej dlja ochistki stochnyh vod: Obzor [Application of environmentally friendly oxidants for wastewater treatment: Overview]. Inform. M.: VNIINTPI, 1990. P. 37-41 (in Russian).

6. Gottschal Ch., Libra J. A., Saupe A. Application of Ozone in Combined Processes. Ozonation of Water and Waste Water: A Practical Guide to Understanding Ozone and its Applications. Second Edition. 2010. P. 267-343.

7. Rakovsky S., Anachkov M., Zaikov G. Fields of ozone applications. Chemistry \& Chemical Technology. 2009. V. 3. No. 2. P. $139-160$.

8. Sanchez-Polo M., von Gunten U., Rivera-Utrilla. Efficiency of activated carbon to transform Ozone OH radicals: Influence of operational parameters. Water Research. 2005. V. 39. P. 3189-3198. DOI: 10.1016/j.watres.2005.05.026

9. Kofman V.Ya. Novye okislitel'nye tehnologii ochistki vody i stochnyh vod. Chast' 1. [New advanced oxidation technologies of water and wastewater treatment (part 1)]. Vodosnabzheniye i sanitarnaya tekhnika [Water Supply and Sanitary Technique]. 2013. No. 10. P. 68-78 (in Russian).

10. Belkov V.M., Choi Sang Won. Metody glubokoj ochistki stochnyh vod ot nefteproduktov [Methods of deep purification of sewage from oil products]. Khimicheskaya promyshlennost [Chemical Industry]. 1998. No. 5. P. 126-128 (in Russian).

11. Oppenlander T. Photochemical Purification of Water and Air. Weincheim: WILEY VCH Verlag, 2003. 368 p.

12. Yogeswary P., Yusof M., Rashid M., Amin S., Aishah N. J. Degradation of phenol by catalytic ozonation. Chemical and Natural Resources Engineering. 2007. V. 2. P.31- 46.

13. Chang C.C., Chiu C.Y., Chang C.Y., Ji D.R. et al. Pt-catalyzed Ozonation of Aqueous Phenol Solution Using Highgravity Rotating Packed Bed. Hazardous Materials. 2009. V. 26. № 3. P. 247-255.

14. Liotta L.F., Gruttadauriab M., Carloc G.D., Perrini G., Librandod V. J. Heterogeneous catalytic degradation of phenolic substrates: Catalysts activity. Hazardous Materials. 2009. V. 26. № 162. P. 588-606.

15. Liou R.M., Chen S.H., Hung M.Y., Hsu C.S., Lai J.Y. Fe (III) supported on resin as effective catalyst for the heterogeneous oxidation of phenol in aqueous solution. Chemosphere. 2005. № 59. P. 117-125.

16. Sukmilin A., Boonchom B., Jarusutthirak C. Catalytic Ozonation using Iron-Doped Water Treatment Sludge as a Catalyst for Treatment of Phenol in Synthetic Wastewater. Environ. Nat. Resour. 2019. V. 17. № 2. P. 87-95.

17. Farzadkia M., Shahamat Y.D, Nasseri S., Mahvi A.H, Gholami M., Shahryari A. Catalytic ozonation of phenolic wastewater: Identification and toxicity of intermediates. Hindawi Publishing Corporation Journal of Engineering. 2014. P. 1-10. DOI: $10.1155 / 2014 / 520929$.

18. Shahamat Y.D, Farzadkia M., Nasseri S, Mahvi A.H, Gholami M., Shahryari A. Magnetic heterogeneous catalytic ozonation: a new removal method for phenol in industrial wastewater. Journal of Environmental Health Science and Engineering. 2014. V. 12(50). P. 1-12.

19. Kasprzyk-Hordern B, Ziółek M, Nawrocki J. Environmental Catalytic ozonation and methods of enhancing molecular ozone reactions in water treatment. Appl Catal Environ. 2003. V. 46. P. 639-669. DOI: 10.1016/S0926-3373(03)00326-6.

20. Tizaoui Ch., Mohammad-Salim H., Suhartono J. Multiwalled Carbon Nanotubes for Heterogeneous Nanocatalyti c Ozonation. Ozone: Science \& Engineering. May-June 2015. № 37. P. 269-278. DOI: 10.1080/01919512.2014.983455.

21. Centurião A. P. S. L., Baldissarelli V. Z., Scaratti G., de Amorim S. M. Enhanced ozonation degradation of petroleum refinery wastewater in the presence of oxide nanocatalysts. Environmental Technology. 2019. V. 40. P. 1239-1249. DOI: 10.1080/09593330.2017.1420103.

22. Khataee A.R., Kasiri M.B. Artificialneural networks modeling of contaminated water treatment processes by homogeneous and heterogeneous nanocatalysis. Journal of Molecular Catalysis A: Chemical. 2010. V. 331. P. 86-100. DOI: 10.1016/j. molcata.2010.07.016. 


\section{СПИСОК ЛИТЕРАТУРЫ}

1. Pisarenko A.N., Stanford B.D., Yan D., Gerrity D., Snyder S.A. Effects of ozone and ozone/peroxide on trace organic contaminants and NDMA in drinking water and water reuse applications // Water Research. - 2012. - V. 46. - P. $316-326$.

2. Ущенко В.П., Попов Ю.В., Воронович Н.В., Узаков Э.Ю., Павлова С.В. Озонирование как способ очистки сточных вод от ароматических соединений // Известия ВолгГТУ. - 2008. - Т. 5, № 1 (39). - С. 79-81.

3. Katsoyiannis I.A., Canonisa S., von Gunten U. Efficiency and energy requirements for the transformation of organic micropollutants by ozone, $\mathrm{O}_{3} / \mathrm{H}_{2} \mathrm{O}_{2}$ and $\mathrm{UV} / \mathrm{H}_{2} \mathrm{O}_{2} / /$ Water Research. -2011 . - V. 45. - P. 3811-3822.

4. Драгинский В.Л., Алексеева В.А., Усольцев В.А. Повышение эффективности очистки воды с использованием технологии озонирования и сорбции на активных углях // Водоснабжение и санитарная техника. $-1995 .-$ Вып. 5. - С. 8-10.

5. Селюков А.В, Бурсова С.Н., Тринко А.И. Применение экологически чистых окислителей для очистки сточных вод: Обзор // Информ. М.: ВНИИНТПИ, 1990. - С. 37-41.

6. Gottschal Ch., Libra J. A., Saupe A. Application of Ozone in Combined Processes. Ozonation of Water and Waste Water: A Practical Guide to Understanding Ozone and its Applications // Second Edition. - 2010. - P. 267-343.

7. Rakovsky S., Anachkov M., Zaikov G. Fields of ozone applications // Chemistry \& Chemical Technology. - 2009. - V. 3. No. 2. - P. 139-160.

8. Sanchez-Polo M., von Gunten U., Rivera-Utrilla. Efficiency of activated carbon to transform Ozone OH radicals: Influence of operational parameters // Water Research. - 2005. - V. 39. - P. 3189-3198.

9. Кофман В.Я. Новые окислительные технологии очистки воды и сточных вод. Часть 1 // Водоснабжение и санитарная техника. - 2013. - № 10. - С. 68-78.

10. Бельков В.М., Чой Санг Уон. Методы глубокой очистки сточных вод от нефтепродуктов // Химическая промышленность. - 1998. - № 5. - С. 126-128.

11. Oppenlander T. Photochemical Purification of Water and Air. - Weincheim: WILEY VCH Verlag, 2003. - 368 p.

12. Yogeswary P., Yusof M., Rashid M., Amin S., Aishah N. J. Degradation of phenol by catalytic ozonation. // Chemical and Natural Resources Engineering. - 2007. - V. 2. - P. 31-46.

13. Chang C.C., Chiu C.Y., Chang C.Y., Ji D.R. et al. Pt-catalyzed Ozonation of Aqueous Phenol Solution Using Highgravity Rotating Packed Bed. // Hazardous Materials. - 2009. - V. 26. - № 3. - P. 247-255.

14. Liotta L.F., Gruttadauriab M., Carloc G.D., Perrini G., Librandod V. J. Heterogeneous catalytic degradation of phenolic substrates: Catalysts activity. // Hazardous Materials. - 2009. - V. 26. - № 162. - P. 588-606.

15. Liou R.M., Chen S.H., Hung M.Y., Hsu C.S., Lai J.Y. Fe (III) supported on resin as effective catalyst for the heterogeneous oxidation of phenol in aqueous solution // Chemosphere. - 2005. - № 59. - P. 117-125.

16. Sukmilin A., Boonchom B., Jarusutthirak C. Catalytic Ozonation using Iron-Doped Water Treatment Sludge as a Catalyst for Treatment of Phenol in Synthetic Wastewater // Environ. Nat. Resour. - 2019. - V. 17. - № 2. - P. 87-95.

17. Farzadkia M., Shahamat Y.D, Nasseri S., Mahvi A.H, Gholami M., Shahryari A. Catalytic ozonation of phenolic wastewater: Identification and toxicity of intermediates. // Hindawi Publishing Corporation Journal of Engineering. - 2014. - P. 1-10. DOI: $10.1155 / 2014 / 520929$.

18. Shahamat Y.D, Farzadkia M., Nasseri S, Mahvi A.H, Gholami M., Shahryari A. Magnetic heterogeneous catalytic ozonation: a new removal method for phenol in industrial wastewater. // Journal of Environmental Health Science and Engineering. - 2014. V. 12(50). - P. 1-12.

19. Kasprzyk-Hordern B, Ziółek M, Nawrocki J. Environmental Catalytic ozonation and methods of enhancing molecular ozone reactions in water treatment. - Appl Catal Environ. - 2003. -V. 46. - P. 639-669. DOI: 10.1016/S0926-3373(03)00326-6.

20. Tizaoui Ch., Mohammad-Salim H., Suhartono J. Multiwalled Carbon Nanotubes for Heterogeneous Nanocatalytic Ozonation // Ozone: Science \& Engineering. May-June - 2015. - № 37. -P. 269-278.

21. Centurião A. P. S. L., Baldissarelli V. Z., Scaratti G., de Amorim S. M. Enhanced ozonation degradation of petroleum refinery wastewater in the presence of oxide nanocatalysts // Environmental Technology. - 2019. - V. 40. - P. $1239-1249$.

22. Khataee A.R., Kasiri M.B. Artificialneural networks modeling of contaminated water treatment processes by homogeneous and heterogeneous nanocatalysis // Journal of Molecular Catalysis A: Chemical.- 2010. - V. 331. P. 86-100. 


\section{INFORMATION ABOUT THE AUTHORS}

Aliya K. Mazitova, Doctor of Chemistry, Professor, Head of Applied and Natural Sciences Department, Ufa State Petroleum Technological University; 1, Kosmonavtov St., Ufa, Republic of Bashkortostan, Russia, 450062; elenaasf@yandex.ru;

Irina A. Sukhareva, PhD in Engineering, Associate Professor, Applied and Natural Sciences Department, Ufa State Petroleum Technological University, 1, Kosmonavtov St., Ufa, Republic of Bashkortostan, Russia, 450062, e-mail: suxareva-ira@yandex.ru;

Alfia F. Aminova, Postgraduate student, Applied ecology Department, Ufa State Petroleum Technological University, 1, Kosmonavtov St., Ufa, Republic of Bashkortostan, Russia, 450062, e-mail: aminovagk@inbox.ru;

Guzel G. Yagafarova, Doctor of Engineering, Professor, Head of Applied ecology Department, Ufa State Petroleum Technological University, 1, Kosmonavtov St., Ufa, Republic of Bashkortostan, Russia, 450062, e-mail: kafedra_ecologia@mail.ru;

Yuliya N. Savicheva, PhD in Engineering, Associate Professor, Industrial Safety and Labor Protection Department, Ufa State Petroleum Technological University, 1, Kosmonavtov St., Ufa, Republic of Bashkortostan, Russia, 450062, e-mail:ufa.savjulia@gmail.com

\section{ИНФОРМАЦИЯ ОБ АВТОРАХ}

Мазитова Алия Карамовна, профессор, зав. кафедрой «Прикладные и естественнонаучные дисциплины», профессор, ФГБОУ ВО «Уфимский государственный нефтяной технический университет», 450062, Россия, Республика Башкортостан, г. Уфа, ул. Космонавтов, 1, e-mail: elenaasf@yandex.ru;

Сухарева Ирина Александровна, доцент кафедры «Прикладные и естественнонаучные дисциплины», кандидат техн. наук, доцент, ФГБОУ ВО «Уфимский государственный нефтяной технический университет», 450062, Россия, Республика Башкортостан, г. Уфа, ул. Космонавтов, 1, e-mail: suxareva-ira@yandex.ru;

Аминова Альфия Фатыховна, аспирант кафедры «Прикладная экология», ФГБОУ ВО «Уфимский государственный нефтяной технический университет», 450062, Россия, Республика Башкортостан, г. Уфа, ул. Космонавтов, 1, e-mail: aminovagk@inbox.ru;

Ягафарова Гузель Габдулловна, профессор, зав. кафедрой «Прикладная экология», доктор техн. наук, профессор, ФГБОУ ВО «Уфимский государственный нефтяной технический университет», 450062, Россия, Республика Башкортостан, г. Уфа, ул. Космонавтов, 1, e-mail: kafedra_ecologia@mail.ru;

Савичева Юлия Николаевна, доцент кафедры «Промышленная безопасность и охрана труда», кандидат техн. наук, ФГБОУ ВО «Уфимский государственный нефтяной технический университет», 450062, Россия, Республика Башкортостан, г. Уфа, ул. Космонавтов, 1, e-mail: ufa.savjulia@gmail.com 